\title{
THE HYPHOMYCETOUS ANAMORPH OF CONIOCYBE FURFURACEA
}

\author{
Rosmarie HONEGGER*
}

\begin{abstract}
Under favourable climatic conditions the mycobiont of Coniocybe furfuracea bears masses of conidia in chains on macronematous conidiophores. The same type of conidia were also formed by axenically grown mycobionts which had been isolated from single ascospores. Germinating conidia were found on the thalli. Coniocybe furfuracea is one of the very few lichen mycobionts so far known with a teleomorph and hyphomycetous anamorph.
\end{abstract}

\section{Introduction}

About 8000 species of lichenized fungi form conidia in pycnidial conidiomata (Vobis \& Hawksworth 1981), some of which represent the coelomycetous anamorph, others spermatial stages or, with high probability, functionless relics of spermatial stages (Vobis 1977, Vobis \& Hawksworth 1981, Honegger 1984a, b). Various lichenized Hyphomycetes have been described (reviewed by Vobis \& Hawksworth 1981), but hyphomycetous anamorphs seem to be extremely rare among lichen-forming fungi with known teleomorphs. The mycobiont of Vezdaea aestivalis forms macronematous conidiophores in the symbiotic state and very soon after germination in pure cultures of ascospores (Tschermak-Woess \& Poelt 1976). Conidial formation was also observed in cultured, but not in free-living symbiotic states of the mycobiont of Pertusaria pertusa (Lallemant $1977 \mathrm{a}, \mathrm{b}$ ). Other reports on hyphomycetous structures in cultured lichen mycobionts (Hale 1957, Ahmadjian 1963) were either not substantiated in subsequent studies (Ahmadjian 1965) or require further examination. Hyphomycete-like structures embedded in the gelatinous thallus which bear spermatia were observed in some Collema species (Bachmann 1912, Degelius 1954), and very peculiar synnematous structures termed hyphophores have been detected in the foliicolous Asterothyriaceae (reviewed by Vobis \& Hawsksworth 1981).

In the course of a study on the mycobiont-phycobiont relationship in Coniocybe furfuracea, many macronematous conidiophores were noted. The relationship of these structures to the teleomorph of Coniocybe furfuracea (Fig. 1) was investigated by means of culture techniques and scanning electron microscopy.

\section{Materials and Methods}

Fresh material was collected in the cold season (November to April 1982/83 and 1983/84) in different locations of central Switzerland. Only very well developed, fertile thalli were used. (1)

*Cytology, Institute of Plant Biology, University of Zürich, CH-8008 Zürich, Switzerland. 
Merliwald W Giswil, NW, $1300 \mathrm{~m}$, November 1982. (2) Ratenpass E Aegeri, SZ, $1000 \mathrm{~m}$, November 1982, March 1983, November 1983. (3) Murgtal S Walensee, SG, 750 m, April 1984, E. Urmi.

Herbarium specimens (Herbarium Institute of Systematic Botany, University of Zürich, Zürich) examined: Switzerland: (1) Höngg bei Felsenegg, ZH, 1900, Hegetschweiler. (2) Salève bei Genf, GE, Schweiz, Bernet [Krypt. exsicc. no. 814]. (3) Hütten bei Zürich, ZH, 1975, $K$. Urmi. (4) Silenen, UR, 1974, K. Urmi. Germany: (1) Wörnbrunn, im Grünewalder Park bei München, 1892, Arnold [Lich. Monacenses exs. no. 225]. (2) Kreuzberger Alpe bei Schliersee, bayr. Alpen, 1882, Arnold.

Isolation of the mycobiont and culture techniques. Mature ascomata were broken off the thallus with the aid of fine, sterile forceps. The surface of a sterile non-nutrient agar (Bold's basal medium, BBM, according to Deason \& Bold 1960) was touched repeatedly with the mazaedium. At each contact of the mazaedium with the agar surface a group of ascospores remained on the agar. The first five groups of each ascoma were discarded in order to eliminate possible contaminants. Dispersion of the ascospores was obtained by spreading the groups of ascospores over the agar surface with the aid of a sterile needle and using a dissecting microscope. The Petri dishes were incubated at $17^{\circ} \mathrm{C}$ at a $14: 10 \mathrm{~h}$ light:dark interval. Germination of ascospores occurred within 1 week and was studied with a Reichert Biovert conversion microscope.

Single spore isolates were transferred either to a nutrient medium containing BBM with $3.5^{\circ} \mathrm{o}$ malt extract, $0.5^{\circ}{ }_{0}$ glucose, $0.05^{\circ}$ o peptone, $0.025^{\circ}{ }_{0}$ casamino acids, and $0.025^{\circ}$ o yeast extract (agar: $1.5_{0}^{\circ}$ ), or to fresh non-nutrient agar (BBM) and covered with the Stichococcus bacillaris phycobiont which had been cultured axenically on the same non-nutrient medium. All strains are kept in our laboratory.

Transmission electron microscopy. See Honegger (1984b).

Scanning electron microscopy (SEM). Lichen thalli or agar blocks with cultured symbionts were exposed to the vapour of a $4 \%$ solution of osmium tetroxide at room temperature overnight, dehydrated in a graded series of acetone, critical point dryed and mounted on specimen stubs with conductive silver print paint (GC Electronics). Mounted specimens were sputter-coated with an alloy of gold and palladium $\left(80^{\circ}, 20^{\circ}{ }_{\circ}\right)$ and examined in a Cambridge Stereoscan $\mathrm{S}-4$.

\section{Results}

In the fluffy thalli of freshly collected and herbarium samples of Coniocybe furfuracea the mycobiont either tightly adheres to or overgrows the chain-like colonies of the ulotrichalean Stichococcus phycobiont, or forms erect hyphae (Fig. 2A-C). In most of the samples examined no special structures could be seen at the tip of the erect hyphae (Fig. 2B). In material collected in late winter (March-April), when the temperature was not too cold and the humidity high due to melting snow around the tree trunks, these erect hyphae produced a mass of conidia, often in chains (Fig. 2D-E) and so represent conidiophores. As the loose thalli of Coniocybe furfuracea are not clearly delimited and yeasts and other conidial fungi can occasionally be seen developing within the tufts, it was not clear whether the abundantly formed conidiophores of the fungus contacting the phycobiont cells were produced by the mycobiont or by another fungus living in the same habitat. Culture experiments became necessary.

Single ascospore isolates of Coniocybe furfuracea were easily obtained (see above). In material collected in the winter months the germination rate was above $90 \%$, and the contamination rate was surprisingly low. When transferred to nutrient agar the mycobiont formed cartilaginous, thallus-like structures with filamentous hyphal growth at the periphery (Fig. 3A), but almost pseudoparenchymatous structures in the older parts. This is a common feature among lichen mycobionts (reviewed by Lallemant 1977b), and the 


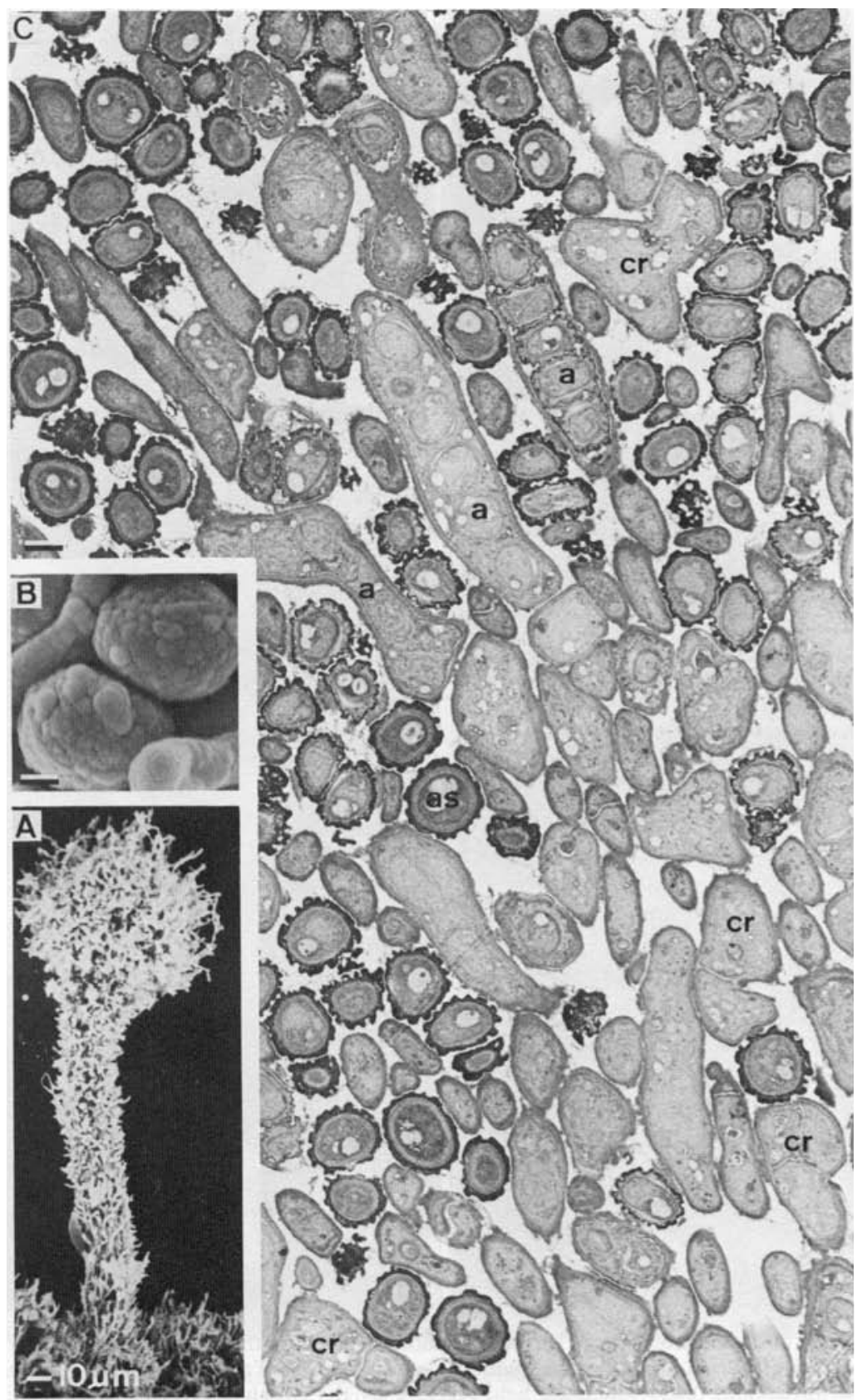

FIG. 1. The teleomorph of Coniocybe furfuracea. A, SEM preparation of a young, not fully developed ascoma, $\times 300 . \mathrm{B}, \mathrm{SEM}$ preparation of two fully differentiated ascospores with characteristically structured exospore, $\times 5000$. C, TEM preparation of a cross-section of part of the mazaedium with different developmental stages of asci (a) and ascospores (as). cr, croziers, $\times 3800$. Scale $=1 \mu \mathrm{m}$ unless otherwise stated. 

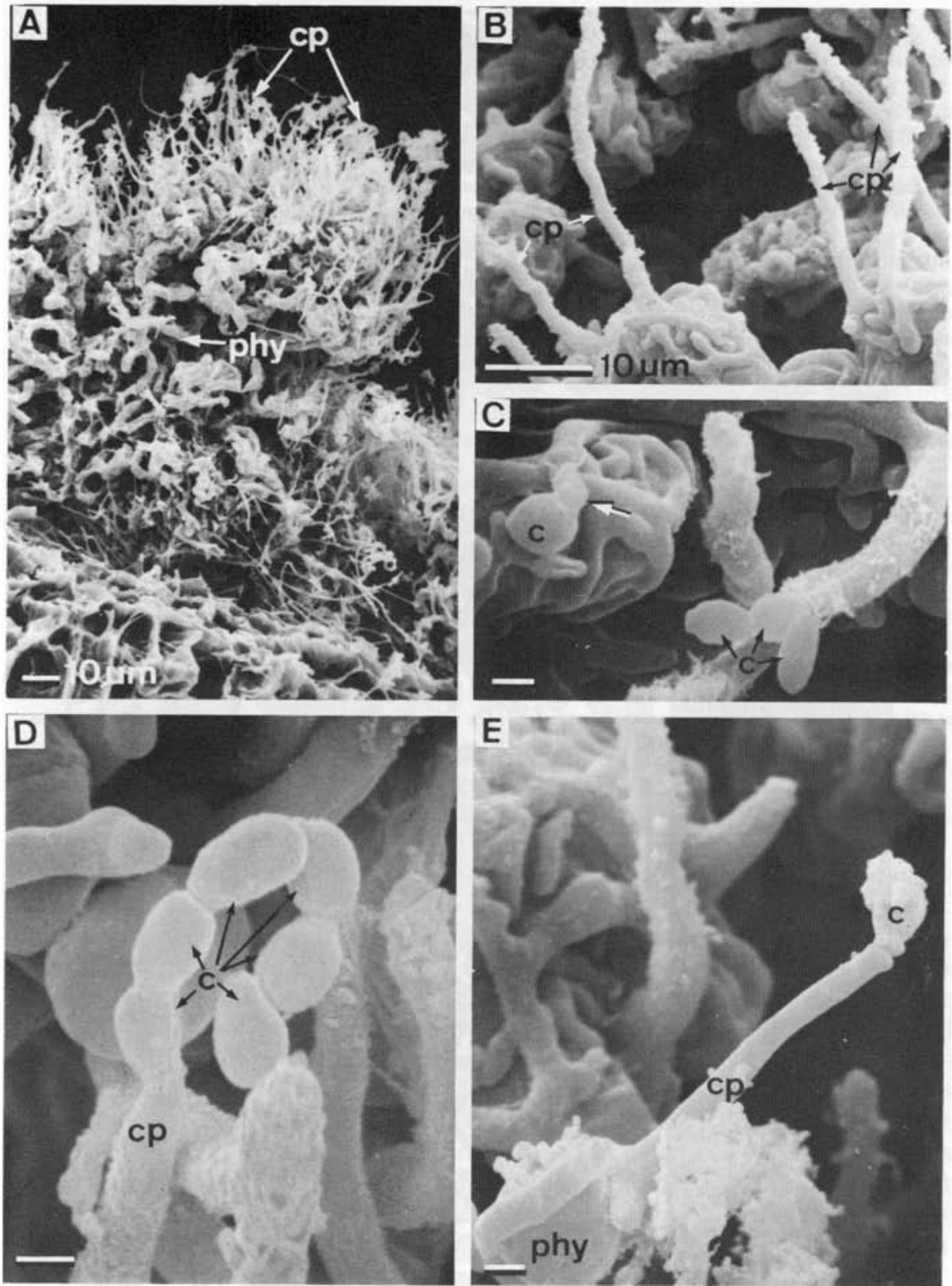

FIG. 2. SEM of thallus morphology and conidiophore structure in the symbiotic (freeliving) state of Coniocyte furfuracea. A, Thalline tuft with chain-like colonies of the ulotrichalean Stichococcus bacillaris phycobiont (phy) which are held together by the closely contacting mycobiont, and numerous erect hyphae of the mycobiont (cp), $\times 460$. B, Phycobiont cells overgrown by the mycobiont, and erect hyphae which represent dormant conidiophores $(\mathrm{cp}), \times 1300$. C, A germinating (arrow) conidium (c) and a chain of conidia (c) on the thallus surface, $\times 4700$. D, Tip of a conidiophore $(\mathrm{cp})$ producing a chain of conidia $(\mathrm{c}), \times 6700 . \mathrm{E}$, Conidiophore producing a conidium (c). Phy, phycobiont cell, $\times 4700$. Scale $=1 \mu \mathrm{m}$ unless otherwise stated. 

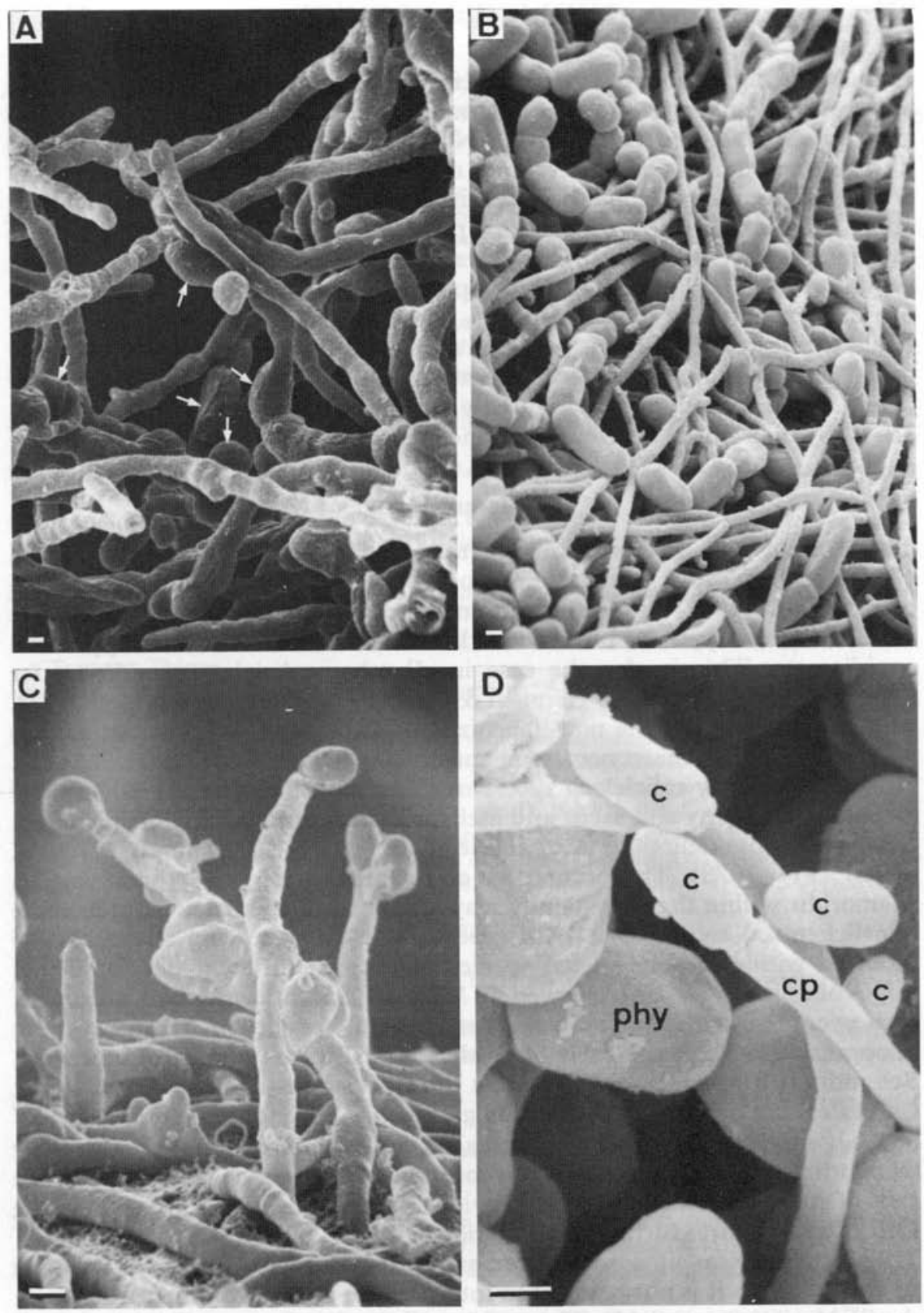

FIG. 3. SEM of growth pattern and conidium formation in axenically cultured Coniocybe furfuracea. A, The growing edge of a thallus-like structure of the mycobiont on nutrient agar with numerous swollen cells (arrows), $\times 2000 . \mathrm{B}$, Filamentous growth of the mycobiont on nonnutrient agar with chain-like colonies of Stichococcus bacillaris, the cultured phycobiont, $\times 1900$. $\mathrm{C}$, Conidiophores and conidia developing on non-nutrient agar without phycobiont cells, $\times 4700$. $\mathrm{D}$, Conidium (c) producing conidiophore (cp) developing in between phycobiont cells (phy) on non-nutrient agar, $\times 8500$. Scale $=1 \mu \mathrm{m}$. 
same is true for the many swollen cells rich in lipid droplets (Fig. 3A) which are produced on nutrient media. On non-nutrient media, filamentous hyphal growth was observed (Fig. 3B-C). No conidiophores were formed on the nutrient medium, but a few developed on the non-nutrient medium (Fig. 3D). A limited number of conidiophores appeared on the non-nutrient medium after addition of the Stichococcus phycobiont (Fig. 3D), although the mycobiont-phycobiont relationship was nowhere as close as in the free-living symbiotic state (Fig. 2B-C). Development from ascospore germination to conidium production took $2 \frac{1}{2}$ months. The culture experiments were carried out in triplicate, with lichens collected at three different sites.

Conidial germination was also observed on the surface of free-living thalli (Fig. 2B). The conidia can be easily distinguished from ascospores (Figs $1 \mathrm{~B}-\mathrm{C}$ ) by their different size, shape, and surface structure.

\section{Discussion}

The present data demonstrate the teleomorph-anamorph relationship in Coniocybe furfuracea, a situation also observed in other calicialean mycobionts. Vobis (1977) reported conidium germination under axenic conditions in Calicium adspersum but there the conidia are formed in pycnidial conidiomata. This is also the case in all other calicialean conidia so far reported (e.g. Galløe 1972, Henssen \& Jahns 1973, Poelt 1974, Tibell 1978), with the exception of the non-lichenized Mycocalicium schefflerae which has a Phialophora-like macronematous anamorph (Samuels \& Buchanan 1983). However, in many calicialean species no data on conidia are available, since ascomatal ontogeny and ascus and ascospore structures are the main characters used in the delimitation of species and genera (e.g. Schmidt 1970a, b, Tibell 1971, 1978). The occurrence of coelomycetous and hyphomycetous anamorphs within the same family may at first seem anomalous, but in some non-lichenized ascomycetes both types of conidium-bearing structures are reported within closely related species or even in different developmental stages of a single species (reviewed by Müller 1981). Sporodochial, acervular, and pycnidial conidiomata were detected in the lichen genus Micarea (Coppins 1983). On the basis of studies on ascomatal and ascal ontogeny, Schmidt (1970b) concluded first, that the Caliciaceae (and even more so the Caliciales) are a very heterogeneous group, and secondly that some species of Coniocybe (including C. furfuracea) and Chaenotheca differ considerably from other Caliciaceae in that ascus formation occurs in chains. Whether the type of conidial formation might provide a further taxonomic criterion in the Caliciaceae requires further investigation.

The mechanism of conidial formation in Coniocybe furfuracea requires further study as it is not possible to interpret the type of conidiogenesis from the SEM pictures available. The conidiophores might represent either true or false chain phialides in the sense of Minter et al. (1982, 1983a, b) or even other types of conidial-bearing structures. Due to the very small size of the conidiogenous cells, only transmission electron microscopic studies will enable a more detailed interpretation to be made. Without these data it is not possible to make comparisons between the conidiophores of Coniocybe 
furfuracea and non-lichenized fungi, although a certain morphological similarity to saprophytes of the genera Humicola and Botryotrichum may be noted.

My sincere thanks are due to Professor E. Müller for stimulating discussions; to Drs Katharina and E. Urmi for the loan of herbarium specimens and collecting fresh material; and to Professor D. L. Hawksworth for valuable comments and for improving the style of this manuscript.

\section{REFERENCES}

Ahmadjian, V. (1963) The fungi of lichens. Sci. Am. 208: 122-132.

Ahmadjian, V. (1965) Lichens. A. Rev. Microbiol. 19: 1-20.

Bachmann, F. M. (1912) A new type of spermogonium and fertilization in Collema. Ann. Bot. London 26: 747-760.

Coppins, B. J. (1983) A taxonomic study of the lichen genus Micarea in Europe. Bull. Br. Mus. nat. Hist. (Bot.) 11: 7-214.

Deason, T. R. \& Bold, H. C. (1960) Phycological studies. I. Exploratory studies of Texas soil algae. Univ. Texas Publ. 6022.

Degelius, G. (1954) The lichen genus Collema in Europe. Symb. Bot. Upsal. 13(2): 1-429.

Galløe, O. (1972) Natural history of the Danish lichens. Vol. 10 (M. S. Christiansen, ed.). Copenhagen: E. Galløe.

Hale, M. E. (1957) Conidial stage of the lichen fungus Buellia stillingiana and its relation to Sporidesmium folliculatum. Mycologia 49: 417-419.

Henssen, A. \& Jahns, H. M. (1973) ['1974'] Lichenes. Eine Einführung in die Flechtenkunde. Stuttgart: 'Thieme.

Honegger, R. (1984a) Scanning electron microscopy of the contact site of conidia and trichogynes in Cladonia furcata. Lichenologist 16: 11-19.

Honegger, R. (1984b) Ultrastructural studies on conidiomata, conidiophores, and conidiogenous cells in six lichen-forming ascomycetes. Can. F. Bot. 62: 2081-2093.

Lallemant, R. (1977a) La morphogenèse du mycobionte du Pertusaria pertusa (L.) Tuck. en cultures pures in vitro. C. R. Acad. Sc. Paris, sér. D, 284: 923-926.

Lallemant, R. (1977b) Recherches sur le développement en cultures pures in vitro du mycobionte du discolichen Pertusaria pertusa (L.) Tuck. Rev. Bryol. Lichénol. 43: 225-282.

Minter, D. W., Kirk, P. M. \& Sutton, B. C. (1982) Holoblastic phialides. Trans, Br. mycol. Soc. 79: 75-93.

Minter, D. W., Kirk, P. M. \& Sutton, B. C. (1983a) Thallic phialides. Trans. Br. mycol. Soc. 80: 39-66.

Minter, D. W., Sutton, B. C. \& Brady, B. L. (1983b) What are phialides anyway? Trans. Br. mycol. Soc. 81: 109-120.

Müller, E. (1981) Relations between conidial anamorphs and their teleomorphs. In Biology of Conidial Fungi (G. T. Cole \& B. Kendrick, eds) Vol. 1: 145-169. New York etc.: Academic Press.

Poelt, J. (1974) ['1973'] Classification. In The Lichens (V. Ahmadjian \& M. E. Hale, eds): 599-632. New York: Academic Press.

Samuels, G. J. \& Buchanan, D. E. (1983) Ascomycetes of New Zealand 5. Mycocalicium schefflerae sp. nov., its ascal ultrastructure and Phialophora anamorph. N. Z. $f l$ Bot. 21: 163-169.

Schmidt, A. (1970a) Anatomisch-taxonomische Untersuchungen an europäischen Arten der Flechtenfamilie Caliciaceae. Mitt. Staatsinst. Allg. Bot. Hamburg 13: 111-166.

Schmidt, A. (1970b) Ascustypen in der Familie Caliciaceae (Ordnung Caliciales). Ber. dtsch. bot. Ges., N.F. 4: 127-137.

Tibell, L. (1971) The genus Cyphelium in Europe. Svensk. bot. Tidskr. 65: 138-164.

Tibell, L. (1978) The genus Microcalicium. Bot. Not. 131: 229-246.

Tschermak-Woess, E. \& Poelt, J. (1976) Vezdaea, a peculiar lichen genus, and its phycobiont. In Lichenology: Progress and Problems (D. H. Brown, D. L. Hawksworth \& R. H. Bailey, eds): 89-105. London: Academic Press.

Vobis, G. (1977) Studies on the germination of lichen conidia. Lichenologist 9: 131-136.

Vobis, G. \& Hawksworth, D. L. (1981) Conidial lichen-forming fungi. In Biology of Conidial Fungi (G. T. Cole \& B. Kendrick, eds) 1: 245-273. New York: Academic Press. 
Downloaded from https:/www.cambridge.org/core. University of Basel Library, on 11 Jul 2017 at 09:05:22, subject to the Cambridge Core terms of use, available at https:/www.cambridge.org/core/terms. https://doi.org/10.1017/S0024282985000354 